\title{
Urinary Fistulae after Radical Ischiectomies in Surgery of Ischial Pressure Sores
}

\author{
I. Eltorai M.D., F. Khonsari M.D., R. Montroy M.D., and A.E. Comarr, \\ M.D. \\ The Spinal Cord Injury Service, Veterans Administration Medical Center, \\ Long Beach, California, the University of California College of Medicine, Irvine, \\ California, the Rancho Los Amigos Medical Center, Downey, California and the \\ Loma Linda University School of Medicine, Loma Linda, California, U.S.A.
}

\section{Summary}

In the early fifties, total ischiectomy was in vogue as a procedure in the surgical treatment of ischial pressure sores. The immediate results by various authors were impressive. One of us, however (A.E.C.), reported the later development of urethral fistulae and the high incidence of perineal urethral diverticulae. The procedure has been abandoned and few surgeons recommend less radical ischiectomy supplemented by muscle transplantation.

Key words: Ischial pressure sores; Radical ischiectomy; Urinary fistulae; Spinal cord injury.

\section{Introduction}

The authors present 10 cases of perineal urethral fistulae, consequent to total ischiectomies. The clinical data are presented in Table 1. Excision and repair with muscle transplant and skin-fat flap repair has been the method of choice in the majority of patients. This was supplemented by suprapubic diversion in most of them and in one patient with bladder neck occlusion. One patient healed without diversion and one healed spontaneously. Another required an ileal conduit with cysto-prostato-urethrectomy. Two developed carcinomas, one in the urethra and one in the bladder and both ended fatally.

It is the opinion of the authors to deplore total ischiectomy in the surgery of ischial pressure sores, because of complete anatomical distortion of the perineum and exposure of the urethra to trauma, diverticulation and fistulisation. With modern muscle transfer and myocutaneous techniques, radical ischiectomy is not needed. An additional observation is that, 60 per cent of the patients developed hip infection and osteomyelitis requiring the Girdlestone Procedure in 40 per cent and hip disarticulation in 20 per cent.

\section{Historical Review}

Total ischiectomy came to be known in the management of ischial pressure sores in the fifth decade of this century. In 1947, Kostrubala and Greeley 
Table 1

\begin{tabular}{|c|c|c|c|c|c|c|c|c|c|}
\hline Name & Age & Injury date & Level & $\begin{array}{c}\text { Date of } \\
\text { ischiectomy }\end{array}$ & $\begin{array}{l}\text { Ischiectomy } \\
\text { uni/bil. }\end{array}$ & $\begin{array}{l}\text { Onset of } \\
\text { fistula }\end{array}$ & $\begin{array}{l}\text { Diverticula } \\
\text { appearance }\end{array}$ & Procedure & Results \\
\hline W.O. & 55 & 1957 & $\mathrm{~T}_{9}$ & 1963 & $\begin{array}{l}\text { Bilateral total with } \\
\text { unilateral hip } \\
\text { disarticulation }\end{array}$ & 1974 & Perineal fistula & $\star$ S.P. Repair & $\begin{array}{l}\text { Failed to heal } \\
\text { CA urethra for which } \\
\text { rad. pelvic/ } \\
\text { excentration Pt. } \\
\text { expired } 3 \text { months later }\end{array}$ \\
\hline G.B. & 57 & 1942 & $\mathrm{~L}_{1}$ & 1962 & $\begin{array}{l}\text { Bilateral total with } \\
\text { unilateral Girdlestone } \\
\text { Procedure }\end{array}$ & 1978 & $\begin{array}{l}\text { Perineal fist. } \\
\text { R. groin } 1980 \\
\text { Suprapubic/1980 }\end{array}$ & $\begin{array}{l}\text { Ureterostomy } \\
\text { Radiotherapy }\end{array}$ & Ca. Sq. cell fatal \\
\hline F.B. & 44 & 1973 & $\mathrm{~T}_{7}$ & 1979 & $\begin{array}{l}\text { Unilateral and } \\
\text { Subtotal }\end{array}$ & 1983 & Unknown & $\begin{array}{l}\text { Spontaneous } \\
\text { healing }\end{array}$ & No recurrence \\
\hline A.D.S & 55 & 1953 & $\mathrm{~T}_{12}$ & 1956 & $\begin{array}{l}\text { Bilateral \& total } \\
\text { with bilateral } \\
\text { Girdlestone } \\
\text { procedure }\end{array}$ & 1974 & Perineal procedure & $\begin{array}{l}\text { Excision \& repair } \\
\text { with muscle flap }\end{array}$ & $\begin{array}{l}\text { Once recurred } \\
\text { Bladder disconnected } \\
\text { No recurrence }\end{array}$ \\
\hline C.H.B. & 43 & 1956 & $\mathrm{~T}_{7}$ & 1960 & Unilateral total & 1980 & Not known & $\begin{array}{l}\text { Excision \& repair } \\
\text { with muscle flap }\end{array}$ & No recurrence \\
\hline G.F. & 46 & 1965 & $\mathrm{~T}_{5}$ & 1970 & $\begin{array}{l}\text { Bilateral total } \\
\text { \& bilateral Girdlestone } \\
\text { Procedure }\end{array}$ & 1973 & Perineal & $\begin{array}{l}\text { Cystectomy, } \\
\text { Urethrectomy } \\
\text { Fistulectomy } \\
\text { Ileal bladder }\end{array}$ & No recurrence \\
\hline L.C. & 36 & 1965 & $\mathrm{~T}_{10}$ & 1976 & $\begin{array}{l}\text { Bilateral subtotal } \\
\text { Bilateral hip } \\
\text { disarticulation }\end{array}$ & 1979 & Perineal & $\star$ S.P. & No recurrence \\
\hline M.M. & 27 & 1975 & $\mathrm{~T}_{3}$ & 1978 & $\begin{array}{l}\text { Bilateral subtotal } \\
\text { with Bilateral } \\
\text { Girdlestone operation }\end{array}$ & 1981 & Perineal & ^ S.P. Local repair & No recurrence \\
\hline D.E.C. & 50 & 1951 & $\mathrm{~T}_{12}$ & 1955 & $\begin{array}{l}\text { Bil. total with } \\
\text { unilateral hip } \\
\text { disarticulation }\end{array}$ & 1982 & Urethral \& bladder & $\star$ S.P. repair & No recurrence \\
\hline J.S. & 30 & 1969 & $\mathrm{~T}_{12}$ & Unknown & $\begin{array}{l}\text { Unilateral subtotal } \\
\text { with Uni. } \\
\text { Girdlestone }\end{array}$ & 1977 & Perineal & Excision \& repair & $\begin{array}{l}\text { Lost } \\
\text { to follow up. }\end{array}$ \\
\hline
\end{tabular}


recommended removal of the bony prominence under all the ulcers surgically treated and for the ischial sores they practiced partial ischiectomy. In 1948, Bors and Comarr recommended excision of the ulcer with part of the ischium, gluteal muscle flap and primary closure. In 1949, Blocksma, Kostrubala and Greeley recommended total ischiectomy which they considered simpler and more satisfactory. In 1950, Marks and Cogbill followed Kostrubala's technique of total ischiectomy; and in the same year, Cannon et al., reported their experience with 45 radical ischiectomies. Comarr and Bors in 1951 reported on 100 cases of total ischiectomy in which bone was removed from the symphysis pubis to the acetabular rim and they considered this technique as the method of choice. Yoeman and Hardy in 1954 reported their surgical results with ulcers in various locations and found that ischiectomy with muscle flap was the best procedure. Then in 1956, Conway and Griffith reported their experience with 1,000 cases; they used the technique of total ischiectomy in 33 cases and concluded that by far the best results were achieved by total ischiectomy together with biceps muscle flap and large regional rotation flap. They had only 3 per cent recurrence from 6 months to 4 years postoperatively.

The remarkable success rate reported by the above authors resulted in the acceptance of total ischiectomy as the preferred procedure in dealing with difficult cases of ischial pressure sores. However, in 1955, Comarr and Bors reported four cases of total ischiectomies complicated by perineal urethral diverticula. The same authors in 1958, after routine cystourethrography in 48 patients who had total ischiectomies found urethral diverticula in 22 of them $(45.8 \%)$. In 12 cases, ischiectomy was unilateral and only one patient had a diverticulum, i.e. 8 per cent, whereas, of 36 patients with bilateral ischiectomies 21 had diverticula $\left(58^{\circ}{ }_{0}\right)$. The onset of diverticula was from 5 months to 11 years post surgery. They postulated that the diverticula resulted from interference with the suspension of the triangular ligament and removal of the ischial tuberosities thus exposing the pars diaphragmatica and pars nuda urethrael to pressure. They refrained from total ischiectomy and recommended sparing the pubic ramus which serves for the attachment of the triangular ligament. They also prohibited total ischiectomy as a prophylactic procedure.

Despite this rather major complication some authors continued to advocate radical ostectomy because of the ease in wound closure and low rate of early complications. For example, Stern et al. (1960) reported four cases of ischiectomy and primary closure with minimal complications although they used less extensive bone removal.

In 1965, Arregui et al. reported their 15 years experience of 94 patients with ischial P.S. Delayed complications developed in 19 per cent of the cases, but they mentioned none in the lower genitourinary tract. They recommended total ischiectomy for the ulcer as well as prophylactically.

In 1973, Spanos et al. reported on 18 extensive ischiectomies in 11 patients, nine of whom had bilateral procedures with minimal recurrence in 2 years. They did not recommend prophylactic total ischiectomy.

\section{The effect of total ischiectomy on the lower urinary tract}

In Comarr-Bors review, 46 per cent of 48 patients who had undergone ischiectomy 
had urethral diverticula, whereas none of 171 patients who had not undergone ischiectomy had diverticula. This implies a causal relationship between ischiectomy and urethral diverticula. This has discouraged most of the surgeons from doing a total ischiectomy during the repair of ischial sores and we belong to this group. In no case was a urethral diverticulum due to obstructive factors before the total removal of the ischium.

However, as recent as 1980, in his book 'Pressure Ulcers', Constantian stated that even though the Comarr-Bors observation is not debated, it has not been confirmed elsewhere in the literature. In his series of 280 patients, 45 (or 16\%) were known to have urethral diverticula, 11 also had bladder diverticula. Of his patients, 61 per cent developed urethral diverticula prior to any type of P.S. surgery. Of the remaining 39 per cent, as many diverticula followed sacral ulcer surgery as followed ischiectomy. Thirty-nine of the diverticula patients had an ischiectomy during their hospital course. In 54 per cent of these patients, the diverticula preceded the ischiectomy by an average span of 5.8 years. In his opinion, Constantian is not convinced by Comarr and Bors report on the issue of the causal effect of ischiectomy in the causation of urinary diverticula. $\mathrm{He}$ attributes the difference of opinion to be due to the limitation of retrospective data, differing patient populations, different decades and different management. However, although he recommends total ischiectomy for ischial sores he is not inclined to carry out the radical procedure, preserving sufficient pubic ramus to keep the triangular ligament intact and protecting the urethra.

In general, the incidence of diverticula varies according to different authors. Comarr and Bors reported a higher incidence, viz. 61 cases amongst 122 patients, or 50 per cent, Bunts 4.6 per cent in 1000 patients and Griffiths and Walsh $9 \cdot 5$ per cent in 200 patients.

\section{Urethral fistulae}

The incidence also varies according to different authors, thus Griffiths and Walsh (1961) reported 31 urethral fistulae amongst 2060 patients seen over 16 years $(1.5 \%)$ and the majority are attributed to long-standing indwelling Foley catheters. Comarr and Bors (1955) reported $445(21 \%)$ penoscrotal lesions amongst 2074 patients whereas Bunts (1970) reported 10.6 per cent amongst 1000 patients.

The commonest causes for urethral fistula in the spinal cord injured is a prolonged indwelling catheter. Other causes are peri-urethral abscess, infection in a diverticulum, accidental trauma (induced or surgical), pressure sores, as a complication of condom drainage, incontinence clamps, external pressure by urinals, improper positioning and inadequate cushioning. The incidence of urethral fistulae in our centre is rare in the last 10 years, because of the use of intermittent catheterisation.

\section{Material}

In this paper, we are presenting ten patients with urinary fistulae. They had had total ischiectomy in the past; a procedure which we currently deplore. They are tabulated in Table 1. 


\section{Discussion}

Ten Veteran Spinal Cord Injury patients were seen with perineal urinary fistulae. Their ages ranged from 27 and 57 years. The cord injury occurred between the years 1942 and 1975. All were paraplegics and their levels of injury varied from $T_{3}$ to $L_{1}$. Five patients had total ischiectomy and one had the procedure unilaterally. Four had subtotal ischiectomies; in two, unilateral; and in the other two bilateral. Five patients subsequently had Girdlestone procedures on the hip, two unilaterally and three bilaterally. Three patients had subsequent hip disarticulations, two unilaterally and one bilaterally. All of the fistulae were perineal. One patient had a perineal fistula together with a right groin fistula. Two patients had multi-locular diverticula, one patient had the fistula bilaterally. Two patients developed carcinomas, one was urethral and one vesical, the latter patient also had the complication of a suprapubic fistula. Four patients had a suprapubic diversion. Cutaneous ureterostomy was done for the patient with cancer of the bladder. One patient had a cystourethrectomy with prostatectomy for massive scarring and was provided with an ileal conduit. The patient who had developed cancer of the urethra had a successful closure of his fistula, but he developed massive haematuria 4 months later and this was diagnosed as cancer of the urethra. Radical pelvic exenteration was done, but the neoplasm recurred and metastases appeared and the patient died 3 months later. Five patients had their fistulae with the diverticula excised, and repair was done with a muscle transplant to the suture line, and covered by a skin-fat flap. Four of these patients had a suprapubic diversion. The fifth patient healed, being treated with an indwelling catheter. One recent patient, healed spontaneously with an indwelling catheter, but has only been followed up for 2 months. One of the five repaired cases had a recurrence for which an operation with the same technique was performed with the addition of bladder neck disconnection, and there has been no recurrence since then. One patient was lost to follow up. Roentgenographic examples are shown in Figures 1 to 5.

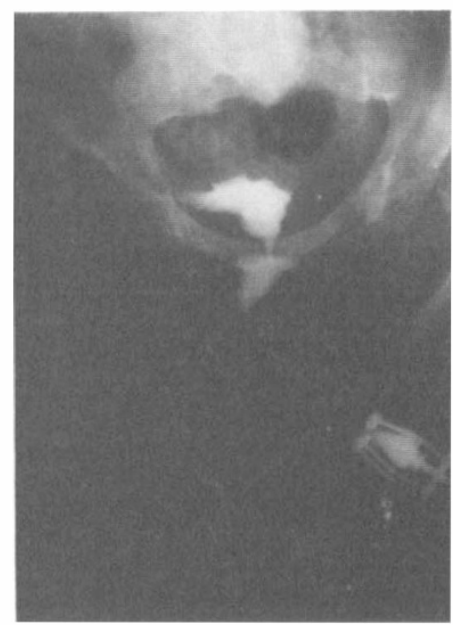

Figure 1. Shows radical ischiectomies and perineal diverticulum. 


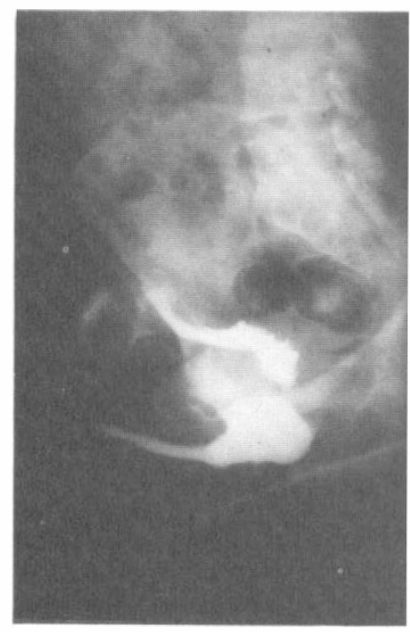

Figure 2. Shows to the left a fistula through recurrent pressure sore.

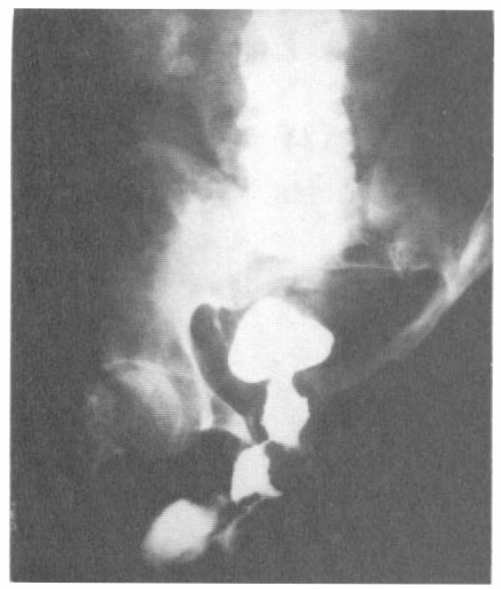

Figure 4. Shows multiple diverticula with extravasation, reflux and kidney calculi.

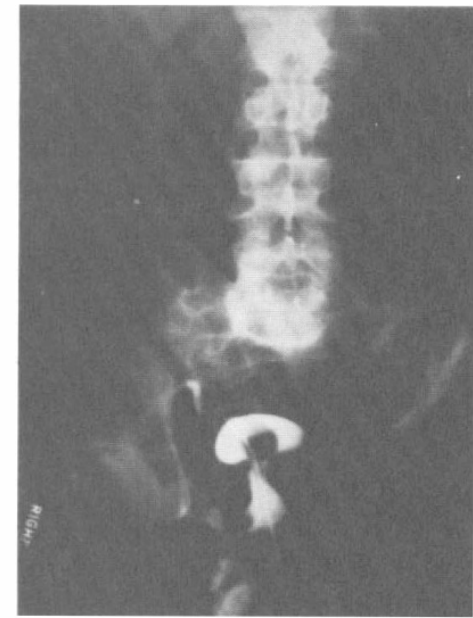

Figure 3. Shows bilateral radical ischiectomy, almost partial pelvectomy, perineal diverticulum and fistula.

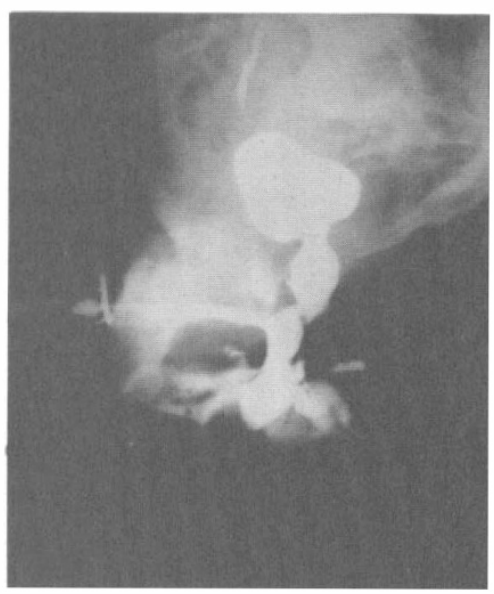

Figure 5. Same case in Figure 4 with further diverticulisation and fistulisation.

Thus, in our view, radical or total ischiectomy for treatment of ischial pressure sores, although it can give immediate good results, the late consequences are serious for the following reasons:

1. It distorts the normal anatomical balance of the pelvis.

2. It distorts the normal anatomical structures of the perineum, especially the perineal fasciae, the urogenital diaphragm and the attached muscles.

3. It causes greater pressure on the perineal urethra by dropping the perineum to a lower level thus exposing it to increasing pressure and shearing during transferring, and possibly also to direct bone injury.

4. With new techniques of muscle transfers and myocutaneous flaps radical ischiectomy should have no place in the repair of ischial pressure sores. 


\section{Résumé}

Les auteurs rapportent dix cas de fistule urinaire basse chez les malades qui out eu l' ischiectomie totale pour la guérison des escarres ischiatiques. Les auteurs ne sont plus d'accord de practiquer cette methode à cause de ses complications notamment les fistules urinaires. Les methodes chirurgicales modernes des lambeaux musculaires et musculocutanés sont satisfaisantes pour le traitement des escarres ischiatiques sans ischiectomie totale.

\section{Zusammenfassung}

Die Verfasser berichten über zehn Patienten mit Harnfistel als konsequente komplikation nach totale ischiektomie für Dekubitalulzera. Die Verfasser empfehlen gegen diese operation wegen die Komplikationen besonderes Harnfistel. Die muskel und Haut-Muskel Lappen bringen den geiwünschten Erfolg ohne radikale Knochen-entfernung.

\section{References}

Arregui J, Cannon B, Murray JE et al. 1965 Long term evaluations of ischiectomy in the treatment of pressure ulcers. Plastic and Reconstructive Surgery 36:583.

Blocksma R, Kostrubala JG, Greeley PW 1949 Surgical repair of decubitus ulcers in paraplegics - further observations. Plastic and Reconstructive Surgery 4:123.

Bors E, Comarr AE 1948 Ischial decubitus ulcer. Surgery 24:680.

BUNTS RC 1970 Surgery of urinary tract dysfunction due to disease or injury of the nervous system. In A.I. Dodson, Jr. Urological Surgery (4th ed.) St. Louis. Mosby: 338-356.

Cannon B, O'Leary J, O’Neil JW 1950 An approach to the treatment of pressure sores. Annals of Surgery 132:760.

COMARR AE, BORS E 1951 Radical ischiectomy in decubitus ischial ulcers complicating paraplegia. Annals of West Medicine Surgery 5:210.

ComArR AE Bors E 1955 Unusual urethral fistula site. American Journal of Surgery 90:151-152.

ComArR AE, Bors E 1958 Perineal urethral diverticulum-complication of removal of ischium. Journal of American Medical Association 168:2000.

Constantian, Mark B 1980 Pressure ulcers. Principles and Techniques of Management. pps. 215-246, Little, Brown and Co., Boston.

Conway H, Griffith BH 1956 Plastic surgery for closure of decubitus ulcers in patients with paraplegia. American Journal of Surgery $91: 946$.

GRIFFITHS IH, WALSH JJ 1961 Diverticula and Fistulae of the urethra in paraplegics. British Journal of Urology 33:374-380.

Kostrubala JB, Greeley PW 1947 The problems of decubitus ulcers in paraplegics. Plastic and Reconstructive Surgery 2:403.

Marks EB, Cogbill CL 1949 Surgical therapy of decubitus ulcers in the paraplegic patient. Annals of Surgery 132:994.

SPANOS PK, MCQUARRIE DG 1973 Early total ischiectomy with primary closure for decubitus ulcers. The American Journal of Surgery 126:98-101.

STERn M, Cozen L, Aldes J 1960 Ischiectomy for pressure sores. California Medicine 93:291. YOEMAN MP, HARDY AG 1954 The pathology and treatment of pressure sores in paraplegics. British Journal of Plastic Surgery 7:179. 